Al Maal : Journal of Islamic Economics and Banking

http://jurnal.umt.ac.id/index.php/jieb

E-ISSN : $2580-3816$

Vol : Vol 2 No. 2 Bulan Januari Tahun 2021

Hlm : $123-142$

DOI : 10.31000/almaal.v2i2.3216

\title{
Analisis Pengaruh Financing To Deposit Ratio, Rasio Efisiensi Kegiatan Operasional, Non Performing Financing, Dan Inflasi Terhadap Return On Asset pada Bank Umum Syariah di Indonesia Periode 2014-2019
}

\author{
Siti Aminatun Jazila ${ }^{1, *}$, Saniman Widodo ${ }^{2}$, Siti Hasanah ${ }^{3}$ \\ 1,2,3 Program Studi Perbankan Syariah, Politeknik Negeri Semarang, Semarang, Indonesia \\ *jazilasitiaminatun09@gmail.com
}

\begin{abstract}
This study aims to analyze the significance effect of Financing to Deposit Ratio (FDR), Operasional Activity Efficiency Ratio (REO), Non Performing Financing (NPF) and Inflation toward Return On Asset (ROA) at Sharia Commercial Banks in Indonesia Period 2014-2019, both simultaneously and partially. The population in this study were all Sharia Commercial Banks in Indonesia period 2014-2019, while the sample in this study were 4 (four) Sharia Commercial Banks in the period of 2014-2019, which were selected using purposive sampling technique. The analysis model in this study is a multiple linear regression analysis model, and the analysis technique used the simultaneous test ( $F$ test), determination coefficient test $\left(R^{2}\right)$, and partial test ( $t$ test). The result of this study showed that the FDR, REO, NPF and Inflation simultaneously have a significant effect toward ROA at Sharia Commercial Banks in Indonesia period 20142019. Furthermore FDR partially has a positive but not significant effect toward ROA, REO partially has a negative and significant effect toward ROA, NPF partially has a negative but not significant effect toward ROA, and Inflation partially has a positive and significant toward ROA at Sharia Commercial Banks in Indonesia period 2014-2019.
\end{abstract}

Keywords: FDR; Inflation; NPF; REO; ROA.

\begin{abstract}
ABSTRAK
Penelitian ini bertujuan untuk menganalisis signifikansi pengaruh Financing to Deposit Ratio (FDR), Rasio Efisiensi Kegiatan Operasional (REO), Non Performing Financing (NPF), dan Inflasi terhadap Return On Asset (ROA) pada Bank Umum Syariah di Indonesia periode 20142019, baik secara simultan maupun parsial. Populasi dalam penelitian ini adalah seluruh Bank Umum Syariah di Indonesia, sedangkan sampel dalam penelitian ini adalah 4 (empat) Bank Umum Syariah di Indonesia periode 2014-2019 yang dipilih menggunakan teknik purposive sampling. Model analisis yang digunakan dalam penelitian ini adalah model analisis regresi linear berganda, sedangkan teknik analisis menggunakan uji signifikansi simultan (uji F), uji koefisien determinasi $\left(R^{2}\right)$, dan uji signifikansi parsial (uji t). Hasil pembuktian hipotesis dan pembahasan menunjukkan FDR, REO, NPF, dan Inflasi secara simultan berpengaruh signifikan terhadap ROA. Selanjutnya FDR secara parsial berpengaruh positif dan tidak signifikan terhadap ROA, REO berpengaruh negatif dan signifikan terhadap ROA, NPF secara parsial berpengaruh negatif dan tidak signifikan terhadap ROA, dan Inflasi berpengaruh positif dan signifikan terhadap ROA pada Bank Umum Syariah di Indonesia periode 2014-2019.
\end{abstract}

Kata kunci: FDR, Inflasi; NPF; REO; ROA. 


\section{Pendahuluan}

Tujuan fundamental bisnis perbankan adalah memperoleh keuntungan optimal dengan jalan memberikan layanan jasa keuangan kepada masyarakat (Kuncoro dan Suhardjono, 2011). Menurut Muhammad (2005), untuk memperoleh keuntungan optimal, bank dituntut untuk melakukan pengelolaan dananya secara efektif dan efisien. Pengelolaan dana yang efektif dan efisien ini dapat meningkatkan produktivitas kerja bank yang selanjutnya akan meningkatkan profitabilitas pada perbankan.

Dalam upaya meningkatkan profitabilitas, bank selalu dihadapkan dengan kepentingan dalam menjaga likuiditas bank (Rivai dan Arifin, 2010). Jika bank hanya mengejar profitabilitas tinggi, besar kemungkinan posisi likuiditasnya terancam. Sebaliknya jika alat-alat likuid menumpuk, penawaran dana akan bertambah yang mengakibatkan menurunnya profitabilitas (Simorangkir, 2004).

Profitabilitas atau disebut dengan rentabilitas adalah kemampuan suatu perusahaan untuk menghasilkan laba selama periode tertentu. Profitabilitas suatu perusahaan menunjukkan perbandingan antara laba dengan aktiva atau modal yang menghasilkan laba tersebut (Riyanto, 2013).

Profitabilitas merupakan salah satu indikator untuk mengukur kinerja keuangan. Kinerja keuangan adalah hasil atau prestasi yang telah dicapai oleh manajemen perusahaan dalam mengelola aset perusahaan secara efektif selama periode tertentu. Kinerja keuangan sangat dibutuhkan oleh perusahaan untuk mengetahui dan mengevaluasi tingkat keberhasilan perusahaan berdasarkan aktivitas keuangan yang telah dilaksanakan (Rudianto, 2013).

Adapun salah satu rasio profitabilitas untuk mengukur kinerja keuangan perusahaan adalah Return On Asset (ROA). ROA digunakan untuk mengukur kemampuan manajemen bank dalam memperoleh keuntungan secara keseluruhan. Ketika ROA yang dihasilkan semakin besar, artinya semakin besar pula tingkat keuntungan yang dicapai bank tersebut, dan semakin baik pula posisi bank tersebut dari segi penggunaan aset (Dendawijaya, 2009).

Naik turunnya Return On Asset (ROA) pada Bank Umum Syariah dapat dipengaruhi oleh beberapa faktor, yaitu faktor internal dan eksternal. Menurut Hidayati (2014), faktor internal merupakan faktor mikro atau faktor spesifik bank yang menentukan profitabilitas, yang dituangkan dalam kinerja keuangan bank seperti rasio Kewajiban Penyediaan Modal Minimum (KPMM), Financing to Deposit Ratio (FDR), Non Performing Financing (NPF), Rasio Efisiensi Kegiatan Operasional (REO) atau Biaya Operasional terhadap Pendapatan Operasional (BOPO). Sedangkan faktor eksternal merupakan faktor yang tidak memiliki hubungan langsung dengan manajemen bank, tetapi faktor tersebut secara tidak langsung memberikan efek bagi perekonomian yang akan berdampak pada kinerja lembaga keuangan, seperti kondisi makroekonomi suatu Negara yang meliputi Inflasi, kurs, dan tingkat suku bunga (BI Rate).

Berdasarkan hal tersebut, maka penelitian ini mengambil beberapa faktor yang mempengaruhi Return On Asset (ROA) yaitu Financing to Deposit Ratio (FDR), Rasio Efisiensi Kegiatan Operasional (REO), Non Performing Financing (NPF), dan Inflasi.

Financing to Deposit Ratio (FDR) merupakan perbandingan antara pembiayaan yang diberikan oleh bank dengan DPK yang berhasil dikerahkan oleh bank. Tinggi rendahnya rasio FDR menunjukkan tingkat likuiditas bank tersebut. Sehingga semakin 
Analisis Pengaruh Financing To Deposit Ratio, Rasio Efisiensi Kegiatan Operasional, Non Performing Financing, Dan Inflasi Terhadap Return On Asset pada Bank Umum Syariah di

tinggi rasio FDR suatu bank, menandakan bank yang kurang likuid dibandingkan dengan bank yang mempunyai angka rasio lebih kecil (Rivai dan Arifin, 2010). sSedangkan hasil penelitian oleh Lemiyana dan Litriani (2016) serta Sumarlin (2016) menyatakan bahwa variabel FDR berpengaruh tidak signifikan terhadap ROA.

Rasio Efisiensi Kegiatan Operasional (REO) digunakan untuk mengukur tingkat efisiensi dan kemampuan bank dalam melakukan kegiatan operasinya. Mengingat kegiatan utama bank pada prinsipnya adalah bertindak sebagai perantara, yaitu menghimpun dan menyalurkan dana (misalnya dana masyarakat), maka biaya dan pendapatan operasional bank didominasi oleh biaya bunga dan hasil bunga. Semakin kecil rasio ini berarti semakin efisien biaya operasional yang dikeluarkan bank yang bersangkutan, sehingga kemungkinan suatu bank berada dalam kondisi bermasalah semakin kecil (Dendawijaya, 2009). Hasil penelitian Janah dan Siregar (2018) serta Syah (2018) menyatakan bahwa REO berpengaruh signifikan terhadap ROA. Sedangkan hasil penelitian Ali, et al., (2011) menyatakan bahwa REO berpengaruh tidak signifikan terhadap ROA.

Non Performing Financing (NPF) adalah rasio antara pembiayaan bermasalah terhadap total pembiayaan yang disalurkan oleh bank syariah. Semakin tinggi rasio NPF, menunjukkan kualitas pembiayaan Bank Syariah akan semakin buruk. Kualitas pembiayaan yang kurang baik atau bahkan memburuk, akan berdampak secara langsung pada penurunan pendapatan dan laba yang diperoleh Bank Syariah. Penurunan pendapatan dan laba tersebut selanjutnya menurunkan kemampuan bank syariah dalam menyalurkan pembiayaan lebih lanjut dan menjalankan bisnis lainnya (IBI, 2015). Hasil penelitian Agustin dan Darmawan (2018) serta Janah dan Siregar (2018) menyatakan bahwa NPF berpengaruh signifikan terhadap ROA. Sedangkan hasil penelitian Ardana (2018) dan Yunita (2014) menyatakan bahwa NPF berpengaruh tidak signifikan terhadap ROA.

Inflasi adalah kenaikan tingkat harga secara umum dari barang atau komoditas dan jasa selama suatu periode waktu tertentu. Inflasi dapat dianggap sebagai fenomena moneter karena terjadinya penurunan nilai unit penghitungan moneter terhadap suatu komoditas. Inflasi berpengaruh buruk terhadap perekonomian, karena menimbulkan gangguan terhadap fungsi uang, terutama terhadap fungsi tabungan (nilai simpan), fungsi dari pembayaran di muka, dan fungsi dari unit penghitungan. Orang harus melepaskan diri dari uang dan aset keuangan akibat dari beban inflasi tersebut (Karim, 2010). Hasil penelitian Ali, et al., (2011) serta Hooshyari dan Moghanloo (2015) menyatakan bahwa Inflasi berpengaruh signifikan terhadap ROA. Sedangkan hasil penelitian Ardana (2018) serta Lemiyana dan Litriani (2016) menyatakan bahwa Inflasi berpengaruh tidak signifikan terhadap ROA.

Berdasarkan fenomena bisnis mengenai Return On Asset (ROA) serta research gap dari hasil penelitian-penelitian terdahulu mengenai faktor-faktor yang mempengaruhi Return On Asset (ROA) pada Bank Umum Syariah di Indonesia, maka hal tersebut menjadi landasan untuk melakukan penelitian dengan judul "Analisis Pengaruh Financing to Deposit Ratio (FDR), Rasio Efisiensi Kegiatan Operasional (REO), Non Performing Financing (NPF), dan Inflasi terhadap Return On Asset (ROA) pada Bank Umum Syariah di Indonesia Periode 2014-2019”. 
Berdasarkan latar belakang masalah, hasil penelitian terdahulu, dan teori pendukung maka rumusan masalah dalam penelitian ini adalah bagaimana pengaruh FDR, REO, NPF, dan Inflasi secara simultan maupun parsial terhadap ROA pada Bank Umum Syariah di Indonesia periode 2014-2019. Sedangkan tujuan penelitian ini adalah untuk menganalisis pengaruh FDR, REO, NPF, dan Inflasi terhadap ROA pada Bank Umum Syariah di Indonesia periode 2014-2019.

\section{KAJIAN LITERATUR Perbankan Syariah}

Berdasarkan Undang-Undang Republik Indonesia Nomor 21 Tahun 2008 tentang Perbankan Syariah, Bank Syariah adalah bank yang menjalankan kegiatan usahanya berdasarkan prinsip syariah dan menurut jenisnya terdiri atas Bank Umum Syariah (BUS) dan Bank Pembiayaan Rakyat Syariah (BPRS).

Prinsip perbankan syariah merupakan bagian dari ajaran Islam yang berkaitan dengan ekonomi. Prinsip syariah berlandaskan pada nilai-nilai keadilan, kemanfaatan, keseimbangan, dan keuniversalan (rahmatan lil 'alamin). Prinsip syariah tersebut meliputi kegiatan usaha yang tidak mengandung unsur-unsur riba, maisir, gharar, haram, dan zalim. Selanjutnya, prinsip perbankan syariah adalah penggunaan sistem/prinsip bagi hasil. Melalui prinsip bagi hasil, bank syariah dapat menciptakan iklim investasi yang sehat dan adil karena semua pihak dapat saling berbagi baik keuntungan maupun potensi risiko yang timbul sehingga akan menciptakan posisi yang berimbang antara bank dan nasabahnya. Dalam jangka panjang, hal ini akan mendorong pemerataan ekonomi nasional karena hasil keuntungan tidak hanya dinikmati oleh pemilik modal saja, tetapi juga oleh pengelola modal.

\section{Return On Asset (ROA)}

Return On Asset (ROA) adalah rasio yang menggambarkan kemampuan bank dalam mengelola dana yang diinvestasikan dalam keseluruhan aset yang menghasilkan keuntungan (Suwiknyo, 2016). Menurut Husnan dan Pudjiastuti 2015), ROA digunakan untuk mengukur efektifitas perusahaan didalam menghasilkan keuntungan dengan memanfaatkan aktiva yang dimilikinya. Semakin besar ROA menunjukkan kinerja keuangan yang semakin baik, karena tingkat kembalian (return) semakin besar.

Return On Asset (ROA) dapat dirumuskan sebagai berikut:

$$
R O A=\frac{\text { Laba Sebelum Pajak }}{\text { Rata }- \text { Rata Total Aset }} \times 100 \%
$$

\section{Financing to Deposit Ratio (FDR)}

Menurut Rivai dan Arifin (2010), FDR adalah perbandingan antara pembiayaan yang diberikan oleh bank dengan Dana Pihak Ketiga (DPK) yang berhasil dikerahkan oleh bank. Rasio ini dipergunakan untuk mengukur sampai sejauh mana dana pinjaman yang bersumber dari DPK. Tinggi rendahnya rasio FDR menunjukkan tingkat likuiditas bank tersebut. Bank wajib menyediakan likuiditas dengan cukup dan mengelolanya dengan baik, karena apabila likuiditas terlalu kecil akan mengganggu kegiatan operasional bank. Namun, likuiditas juga tidak boleh terlalu besar, karena akan menurunkan efisiensi bank sehingga berdampak pada rendahnya tingkat profitabilitas. 
Analisis Pengaruh Financing To Deposit Ratio, Rasio Efisiensi Kegiatan Operasional, Non Performing Financing, Dan Inflasi Terhadap Return On Asset pada Bank Umum Syariah di

FDR mempunyai peranan yang sangat penting sebagai indikator yang menunjukkan tingkat ekspansi pembiayaan yang dilakukan bank sehingga FDR dapat juga digunakan untuk mengukur berjalan tidaknya suatu fungsi intermediasi bank (Suwiknyo 2016).

Financing to Deposit Ratio (FDR) dapat dirumuskan sebagai berikut:

$$
F D R=\frac{\text { Total Pembiayaan }}{\text { Dana Pihak Ketiga }} \times 100 \%
$$

\section{Rasio Efisiensi Kegiatan Operasional (REO)}

Rasio Efisiensi Kegiatan Operasional (REO) adalah rasio yang digunakan untuk mengetahui tingkat efisiensi bank menjalankan operasinya. Artinya semakin besar REO menunjukkan kegiatan perusahaan yang semakin tidak efisien, dan semakin kecil rasio ini justru akan menunjukkan kegiatan perusahaan yang semakin efisien (Taswan, 2017). Menurut Muhamad (2016), beban (expense) adalah biaya yang secara langsung atau tidak langsung telah dimanfaatkan di dalam usaha menghasilkan pendapatan dalam suatu periode atau yang sudah tidak memberikan manfaat ekonomis untuk kegiatan masa berikutnya. Sedangkan pengahasilan (revenue) adalah peningkatan jumlah harta atau penurunan kewajiban suatu badan usaha yang timbul dari penyerahan barang dagang atau jasa ataupun aktivitas usaha lainnya di dalam suatu periode.

Rasio Efisiensi Kegiatan Operasional (REO) dapat dirumuskan sebagai berikut:

$$
R E O=\frac{\text { Beban Operasional }}{\text { Pendapatan Operasional }} \times 100 \%
$$

\section{Non Performing Financing (NPF)}

Rasio Non Performing Financing (NPF) adalah perbandingan antara pembiayaan bermasalah terhadap total pembiayaan (Taswan, 2017). Kualitas pembiayaan suatu Bank Syariah dapat digambarkan dari kemampuan Bank Syariah untuk memperoleh kembali seluruh pembiayaan yang diberikan kepada nasabah pembiyaan sampai lunas. Tinggi rendahnya rasio NPF menunjukkan kualitas pembiayaan bank syariah. Semakin tinggi rasio NPF, menunjukkan kualitas pembiayaan Bank Syariah akan semakin buruk. Kualitas pembiayaan yang kurang baik atau bahkan memburuk, akan berdampak secara langsung pada penurunan pendapatan dan laba yang diperoleh Bank Syariah (IBI, 2015).

Non Performing Financing (NPF) dapat dirumuskan sebagai berikut:

$$
N P F=\frac{\text { Pembiayaan Bermasalah }}{\text { Total Pembiayaan }} \times 100 \%
$$

\section{Inflasi}

Definisi inflasi oleh para ekonom modern adalah kenaikan yang menyeluruh dari jumlah uang yang harus dibayarkan (nilai unit penghitungan moneter) terhadap barangbarang atau komoditas dan jasa. Sebaliknya, jika yang terjadi adalah penurunan nilai unit penghitungan moneter terhadap barang-barang atau komoditas dan jasa didefinisikan sebagai deflasi (deflation) (Karim, 2010). Indikator yang pada umumnya digunakan untuk 
mengetahui laju inflasi adalah Indeks Harga Konsumen (Consumer Price Index). Indeks harga konsumen adalah angka indeks yang menunjukkan tingkat harga barang dan jasa yang harus dibeli konsumen dalam satu periode tertentu. Angka IHK diperoleh dengan menghitung harga-harga barang dan jasa utama yang dikonsumsi masyarakat dalam satu periode tertentu. Masing-masing harga barang dan jasa tersebut diberi bobot (weighted) berdasarkan tingkat keutamaannya. Barang dan jasa yang dianggap penting diberi bobot yang paling besar.

Inflasi dapat dirumuskan sebagai berikut:

$$
\text { Inflasi }=\frac{I H K n-I H K n-1}{I H K n-1} \times 100 \%
$$

\section{Pengaruh Antar Variabel \\ Pengaruh FDR terhadap ROA}

Menurut Muhammad (2005), FDR dipergunakan untuk mengukur sampai sejauh mana dana pinjaman yang bersumber dari Dana Pihak Ketiga (DPK). Nilai FDR menunjukkan efektif tidaknya bank dalam menyalurkan pembiayaan. Apabila nilai FDR menunjukkan persentase tinggi, menandakan dana pihak ketiga yang disalurkan melalui pembiayaan semakin tinggi. Pembiayaan yang disalurkan secara optimal dan efektif, akan meningkatkan pendapatan bank yang selanjutnya akan meningkatkan pula laba atau profitabilitas yang diperoleh bank syariah. Sebaliknya, nilai FDR yang rendah, menandakan pihak bank kurang optimal dan efektif dalam penyaluran pembiayaan, sehingga pendapatan dan laba yang diperoleh juga sedikit (Riyadi dan Yulianto, 2014).

\section{Pengaruh REO terhadap ROA}

REO digunakan mengukur tingkat efisiensi dan kemampuan bank dalam menunjang kegiatan operasional. Semakin kecil rasio biaya (beban) operasionalnya akan lebih baik, karena biaya yang dikeluarkan lebih kecil dibandingkan pendapatan yang diterima. Adanya efisiensi biaya pada lembaga perbankan, akan diperoleh tingkat pendapatan yang optimal, yang selanjutnya semakin meningkatkan laba atau profitabilitas bank syariah. Selain itu dengan semakin tingginya laba bank syariah, berpengaruh kepada penambahan jumlah dana yang disalurkan, biaya lebih kompetitif, peningkatan pelayanan kepada nasabah, serta peningkatan keamanan dan kesehatan bank. Sebaliknya, semakin tinggi biaya operasional menandakan bank syariah semakin tidak efisien dalam kegiatan operasionalnya, yang berpengaruh kepada penurunan pendapatan dan selanjutnya akan menurunkan laba atau profitabilitas bank syariah (Rivai dan Arifin, 2010).

\section{Pengaruh NPF terhadap ROA}

Non Performing Financing (NPF) merupakan rasio untuk mengetahui kualitas pembiayaan bank syariah. Semakin tinggi rasio NPF, menunjukkan kualitas pembiayaan Bank Syariah akan semakin buruk. Kualitas pembiayaan yang kurang baik atau bahkan memburuk, akan berdampak secara langsung pada penurunan pendapatan dan laba yang diperoleh Bank Syariah. Penurunan pendapatan dan laba tersebut selanjutnya menurunkan kemampuan bank syariah dalam menyalurkan pembiayaan lebih lanjut dan menjalankan bisnis lainnya (IBI, 2015). 
Analisis Pengaruh Financing To Deposit Ratio, Rasio Efisiensi Kegiatan Operasional, Non

Performing Financing, Dan Inflasi Terhadap Return On Asset pada Bank Umum Syariah di

\section{Pengaruh Inflasi terhadap ROA}

Inflasi dapat berpengaruh buruk terhadap perekonomian, karena apabila terjadi inflasi yang parah maka keadaan perekonomian menjadi tidak stabil. Hal ini mengakibatkan minat masyarakat untuk menabung atau berinvestasi menjadi berkurang serta menyebabkan adanya peningkatan pembiayaan bermasalah akibat nasabah tidak mampu membayar kembali pembiayaan yang ia terima. Ketika terjadi inflasi masyarakat lebih fokus pada kebutuhan primer, sehingga semua pendapatan yang mereka terima akan mereka belanjakan untuk kebutuhan pokok mereka, terutama pangan. Efek inflasi akan semakin terlihat pada masyarakat dengan pendapatan tetap. Selain itu, perusahaan sektor riil juga enggan untuk menambah modal guna membiayai produksinya, yang pada akhirnya akan berdampak pada turunnya profitabilitas bank syariah (Sumarlin, 2016).

\section{Hipotesis}

Hipotesis yang diajukan dalam penelitian ini sebagai berikut:

$\mathrm{H}_{1}$ : Diduga FDR, REO, NPF, dan Inflasi secara simultan berpengaruh signifikan terhadap ROA pada Bank Umum Syariah di Indonesia Periode 2014 - 2019.

$\mathrm{H}_{2}$ : FDR secara parsial berpengaruh signifikan terhadap ROA pada Bank Umum Syariah di Indonesia Periode 2014 - 2019.

$\mathrm{H}_{3}$ : REO secara parsial berpengaruh signifikan terhadap ROA pada Bank Umum Syariah di Indonesia Periode 2014 - 2019.

$\mathrm{H}_{4}$ : FDR secara parsial berpengaruh signifikan terhadap ROA pada Bank Umum Syariah di Indonesia Periode 2014 - 2019.

$\mathrm{H}_{5}$ : FDR secara parsial berpengaruh signifikan terhadap ROA pada Bank Umum Syariah di Indonesia Periode 2014 - 2019

\section{Metode Penelitian \\ Metode Pengumpulan Data}

Data yang digunakan dalam penelitian ini adalah data sekunder. Data sekunder adalah data yang terlebih dahulu dikumpulkan dan dilaporkan oleh orang atau instansi di luar dari peneliti sendiri (melalui pihak lain) dan didapatkan secara tidak langsung dari subjek penelitiannya (Kuncoro, 2013). Data dalam penelitian ini diperoleh dari laporan publikasi triwulan Bank Umum Syariah (BUS) serta laporan publikasi dari Bank Indonesia (BI) periode 2014-2019.

\section{Populasi dan Sampel}

Populasi dalam penelitian ini adalah 14 (empat belas) Bank Umum Syariah di Indonesia. Sampel dalam penelitian ini adalah 4 (empat) Bank Umum Syariah di Indonesia yang memenuhi kriteria purposive sampling, yaitu Bank Muamalat Indonesia, Bank Rakyat Indonesia Syariah, Tbk., Bank Negara Indonesia Syariah, dan Bank Syariah Mandiri. 


\section{Pengujian Data}

Uji Normalitas

Uji normalitas bertujuan untuk menguji apakah dalam model regresi, variabel dependen dan variabel independen keduanya memiliki distribusi normal atau tidak (Ghozali, 2006).

Uji Asumsi Klasik

Dilakukan dengan melakukan pengujian terhadap 3 (tiga) uji asumsi klasik meliputi, Uji Multikolonearitas, Heteroskedastisitas, dan Autokorelasi.

Model Analisis Regresi Linier Berganda

Model yang digunakan adalah analisis regresi linier berganda dengan alat bantu SPSS 16.00, analisis regresi digunakan untuk mengukur besarnya arah perngaruh variabel independen terhadap variabel dependen. Persamaan regresi juga disebut sebagai model regresi, adalah sebagai berikut:

$$
Y=\alpha+\beta_{1} X_{1}-\beta_{2} X_{2}-\beta_{3} X_{3}-\beta_{4} X_{4}+e
$$

Keterangan:

$$
\begin{array}{ll}
\mathrm{Y}=\text { Return On Asset }(\mathrm{ROA}) & \mathrm{X}_{2}=\text { Rasio Efisiensi Kegiatan Operasional } \\
\mathrm{a}=\text { Konstanta Persamaan Regresi } & \mathrm{X}_{3}=\text { Non Performing Financing (NPF) } \\
\beta_{1 \ldots \beta_{4}=\text { Koefisien Regresi Parsial }} & \mathrm{X}_{4}=\text { Inflasi } \\
\text { Variabel } \mathrm{X}_{1}, \mathrm{X}_{2}, \mathrm{X}_{3}, \mathrm{X}_{4} &
\end{array}
$$$$
\mathrm{X}_{1}=\text { Financing to Deposit Ratio }(\mathrm{FDR}) e=\text { Komponen Kesalahan Random }
$$$$
\text { (random error) }
$$

\section{Teknik Analisis Data}

Menggunakan Uji F Statistik, Uji Koefisien Determinasi $\left(\mathrm{R}^{2}\right)$, dan Uji t Statistik.

\section{Hasil dan Pembahasan \\ Uji Normalitas} Gambar 2.

Hasil uji normalitas dengan analisis grafik, dapat dilihat pada Gambar 1 dan Gambar 1. Grafik Histogram

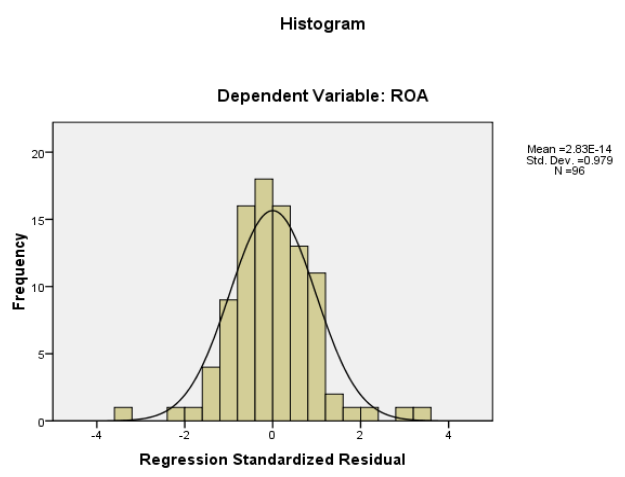

Sumber: Data Sekunder, diolah dengan SPSS 16.00. 
Analisis Pengaruh Financing To Deposit Ratio, Rasio Efisiensi Kegiatan Operasional, Non Performing Financing, Dan Inflasi Terhadap Return On Asset pada Bank Umum Syariah di Indonesia Periode 2014-2019

Gambar 2. Grafik Normal P-Plot

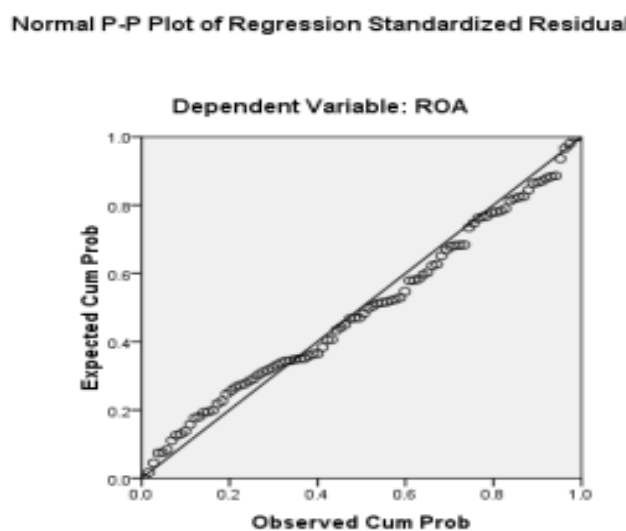

Sumber: Data Sekunder, diolah dengan SPSS 16.00.

Berdasarkan Gambar 1 menunjukkan bahwa sebagian besar bar pada grafik histogram berada di bawah kurva, maka residual dinyatakan berdistribusi normal. Kemudian Gambar 2 menunjukkan titik-titik pada grafik normal P-Plot menyebar di sekitar garis diagonal dan mengikuti arah garis diagonal. Maka dapat disimpulkan bahwa data berdistribusi normal (Ghozali, 2006).

Selain menggunakan analisis grafik, pengujian normalitas dapat ditunjukkan melalui analisis statistik yaitu dengan uji Non-Parametrik Kolmogorov-Smirnov (K-S), yang dapat dilihat pada Tabel 1.

Tabel 1. Uji Non-Parametrik Kolmogorov-Smirnov (K-S)

\section{One-Sample Kolmogorov-Smirnov Test}

\begin{tabular}{lll}
\hline & & Unstandardized Residual \\
$N$ & & 96 \\
Normal Parameters & \\
& Mean & .0000000 \\
Most Extreme Differences & Std. Deviation & .11534230 \\
& Absolute & .064 \\
& Positive & .064 \\
Kolmogorov-Smirnov Z & Negative & -.057 \\
Asymp. Sig. (2-tailed) & & .625 \\
a. Test distribution is Normal. & & .830 \\
\hline
\end{tabular}

Sumber: Data Sekunder, diolah dengan SPSS 16.00.

Berdasarkan Tabel 1 menunjukkan nilai signifikansi hasil uji Non-Parametrik Kologorov-Smirnov (K-S) sebesar 0,830 lebih besar dari 0,05. Hal tersebut mengindikasikan bahwa nilai signifikan > 0,05, maka dapat disimpulkan bahwa data berdistribusi normal (Ghozali, 2006). 


\section{Uji Asumsi Klasik}

Uji Multikolinearitas

Hasil uji multikolinearitas dapat dilihat pada Tabel 2.

Tabel 2. Uji Multikolinearitas

\section{Coefficients $^{a}$}

Model

Collinearity Statistics

Tolerance VIF

$1 \quad$ (Constant)

$\begin{array}{lll}\text { FDR } & 0.609 & 1.643 \\ \text { REO } & 0.542 & 1.845 \\ N P F & 0.531 & 1.884 \\ \text { INFLASI } & 0.638 & 1.568\end{array}$

a. Dependent Variable: ROA

Sumber: Data Sekunder, diolah dengan SPSS 16.00.

Berdasarkan Tabel 2 menunjukkan bahwa seluruh variabel independen yang terdiri dari FDR, REO, NPF, dan Inflasi memiliki nilai Tolerance lebih dari 0,1 dan nilai VIF kurang dari 10. Hal ini dapat disimpulkan bahwa tidak terdapat multikolinearitas pada variabel independen pada model regresi (Ghozali, 2006).

Uji Heteroskedastisitas

Hasil uji heteroskedastisitas dengan analisis grafik yaitu grafik scatterplot, dapat dilihat pada Gambar 3.

\section{Gambar 3. Grafik Scatterplot}

Scatterplot

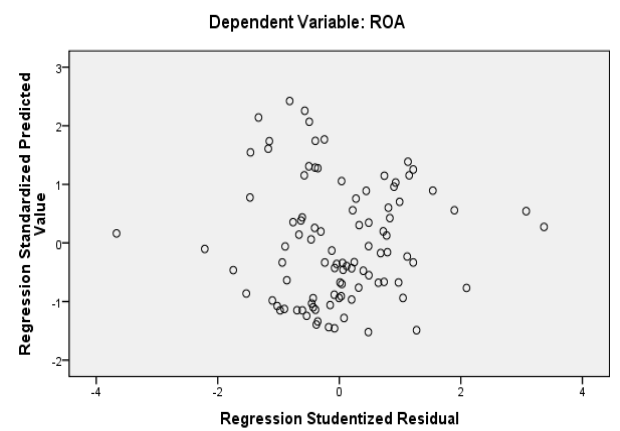

Sumber: Data Sekunder, diolah dengan SPSS 16.00.

Berdasarkan Gambar 3 menunjukkan titik-titik pada grafik Scatterplot menyebar secara acak (tidak ada pola tertentu), serta tersebar di atas maupun di bawah angka 0 pada sumbu Y. Sehingga dapat disimpulkan bahwa dalam penelitian ini tidak terjadi heteroskedastisitas. 
Analisis Pengaruh Financing To Deposit Ratio, Rasio Efisiensi Kegiatan Operasional, Non Performing Financing, Dan Inflasi Terhadap Return On Asset pada Bank Umum Syariah di Indonesia Periode 2014-2019

Selain menggunakan analisis grafik, pengujian heteroskedastisitas dapat ditunjukkan melalui uji statistik yaitu uji Park, yang dapat dilihat pada Tabel 3.

\begin{tabular}{|c|c|c|c|c|c|c|}
\hline & \multicolumn{6}{|c|}{ Tabel 3. Uji Park } \\
\hline & & Unstan & rdized & Standardized & & \\
\hline \multicolumn{2}{|c|}{ Model } & \multicolumn{2}{|c|}{ Coefficients } & Coefficients & $t$ & Sig. \\
\hline & & $B$ & Std. Error & Beta & & \\
\hline 1 & (Constant) & 0.976 & 6.005 & & 0.162 & 0.872 \\
\hline & $F D R$ & 0.057 & 0.033 & 0.319 & 1.760 & 0.086 \\
\hline & $R E O$ & -0.100 & 0.075 & -0.305 & -1.328 & 0.192 \\
\hline & $N P F$ & 0.036 & 0.194 & 0.046 & 0.186 & 0.853 \\
\hline & INFLASI & 0.054 & 0.126 & 0.070 & 0.425 & 0.673 \\
\hline
\end{tabular}

a. Dependent Variable: LN_Res

Sumber: Data Sekunder, diolah dengan SPSS 16.00.

Berdasarkan Tabel 3 menunjukkan bahwa tidak ada variabel independen yang signifikan atau lebih dari 0,05. Maka dapat disimpulkan bahwa tidak terdapat heteroskedastisitas pada model regresi (Ghozali, 2006).

\section{Uji Autokorelasi}

Hasil uji autokorelasi dengan uji Durbin-Watson, dapat dilihat pada Tabel 4.

Tabel 4. Uji Durbin Watson

\begin{tabular}{|c|c|c|c|c|c|}
\hline \multicolumn{6}{|c|}{ Model Summary } \\
\hline Model & $R$ & R Square & $\begin{array}{l}\text { Adjusted } R \\
\text { Square }\end{array}$ & $\begin{array}{l}\text { Std. Error of the } \\
\text { Estimate }\end{array}$ & $\begin{array}{l}\text { Durbin- } \\
\text { Watson }\end{array}$ \\
\hline 1 & $0.977^{a}$ & 0.954 & 0.952 & 0.11785 & 0.865 \\
\hline \multicolumn{6}{|c|}{ a. Predictors: (Constant), INFLASI, REO, NPF, FDR } \\
\hline b. Depe & Varia & & & & \\
\hline
\end{tabular}

Sumber: Data Sekunder, diolah dengan SPSS 16.00.

Berdasarkan Tabel 4 menunjukkan nilai Durbin Watson sebesar 0,865 yang berada di antara angka -2 dan 2 . Hal ini dapat disimpulkan bahwa dalam penelitian ini tidak terjadi gejala autokorelasi (Sunyoto, 2011). 


\section{Analisis Regresi Linear Berganda}

Hasil analisis regresi linear berganda, dapat dilihat pada Tabel 5.

Tabel 5. Analisis Regresi Linear Berganda

a. Dependent Variable: ROA

Sumber: Data Sekunder, diolah dengan SPSS 16.00. berikut:

Berdasarkan Tabel 5 dapat dirumuskan persamaan regresi linear berganda sebagai

$$
R O A=9,994+0,002 F D R-0,102 R E O-0,007 N P F+0,019 \text { Inflasi }+e
$$

\section{Pembuktian Hipotesis}

Pengujian hipotesis bertujuan mengukur ketepatan fungsi regresi dalam menaksir nilai aktual yang diukur dari goodness of fit. Secara statistik, hal ini dapat diukur melalui uji F, koefisien determinasi $\left(\mathrm{R}^{2}\right)$, dan uji $\mathrm{t}$ (Ghozali, 2006).

\section{Uji Signifikansi Simultan (Uji F)}

Uji F pada dasarnya menunjukkan apakah semua variabel independen (FDR, REO, NPF, dan Inflasi) yang dimasukkan dalam model dan mempunyai pengaruh secara bersama-sama (simultan) terhadap variabel dependen (ROA) (Ghozali, 2006). Adapun hasil uji F terlihat pada Tabel 6.

\begin{tabular}{lllllll}
\hline \multicolumn{5}{c}{ Tabel 6. Uji F } \\
\hline \multicolumn{5}{c}{ ANOVA $^{a}$} \\
Model & Sum of Squares & $d f$ & $\begin{array}{l}\text { Mean } \\
\text { Square }\end{array}$ & $F$ & Sig. \\
1 & Regression & 26.084 & 4 & 6.521 & 469.526 & $0.000^{a}$ \\
& Residual & 1.264 & 91 & 0.014 & & \\
& Total & 27.348 & 95 & & &
\end{tabular}

a. Predictors: (Constant), INFLASI, NPF, FDR, REO

b. Dependent Variable: ROA

Sumber: Data Sekunder, diolah dengan SPSS 16.00.

Pembuktian hipotesis 1 (satu) dilakukan dengan uji F. Berdasarkan Tabel 6 dihasilkan $F_{\text {hitung }}=469.526>F_{\text {tabel }}=2,47$ atau signifikansi $0,000<0,05$, yang berarti 
Analisis Pengaruh Financing To Deposit Ratio, Rasio Efisiensi Kegiatan Operasional, Non Performing Financing, Dan Inflasi Terhadap Return On Asset pada Bank Umum Syariah di Indonesia Periode 2014-2019

terdapat pengaruh yang signifikan antara variabel FDR, REO, NPF, dan Inflasi secara simultan terhadap ROA.

Dengan demikian, hipotesis 1 (satu) yang menyatakan "Diduga FDR, REO, NPF, dan Inflasi secara simultan berpengaruh signifikan terhadap ROA pada Bank Umum Syariah di Indonesia Periode 2014-2019”, dinyatakan diterima.

Uji $R^{2}$

Menurut Ghozali (2006), koefisien determinasi $\left(\mathrm{R}^{2}\right)$ pada intinya mengukur seberapa jauh kemampuan model dalam menerangkan variasi variabel dependen. Nilai koefisien determinasi adalah antara 0 (nol) sampai 1 (satu). Hasil uji koefisien determinasi $\left(\mathrm{R}^{2}\right)$ dalam penelitian ini dapat dilihat pada Tabel 7.

Tabel 7. Uji $R^{2}$

\begin{tabular}{|c|c|c|c|c|c|}
\hline \multicolumn{6}{|c|}{ Model Summary ${ }^{b}$} \\
\hline Model & $R$ & R Square & $\begin{array}{l}\text { Adjusted } \\
\text { Square }\end{array}$ & $R$ & $\begin{array}{l}\text { Std. Error of the } \\
\text { Estimate }\end{array}$ \\
\hline 1 & $0.977^{a}$ & 0.954 & 0.952 & & 0.11785 \\
\hline \multicolumn{6}{|c|}{ a. Predictors: (Constant), INFLASI, REO, NPF, FDR } \\
\hline
\end{tabular}

Sumber: Data Sekunder, diolah dengan SPSS 16.00.

Berdasarkan Tabel 7 dihasilkan nilai Adjusted $R$ Square pada uji koefisien determinasi $\left(\mathrm{R}^{2}\right)$ adalah 0,952 atau $95,2 \%$. Hal ini menunjukkan bahwa variabel FDR, REO, NPF, dan Inflasi memberikan kontribusi pengaruh terhadap ROA sebesar 95,2 \%, sedangkan 4,8 \% sisanya dipengaruhi oleh variabel lain yang tidak diteliti dalam penelitian ini.

\section{Uji Signifikansi Parsial (Uji t)}

Uji statistik t pada dasarnya menunjukkan seberapa jauh pengaruh satu variabel penjelas/independen secara individual dalam menerangkan variasi variabel dependen (Ghozali, 2006). Hasil uji t dapat dilihat pada Tabel 8.

Tabel 8. Uji $t$

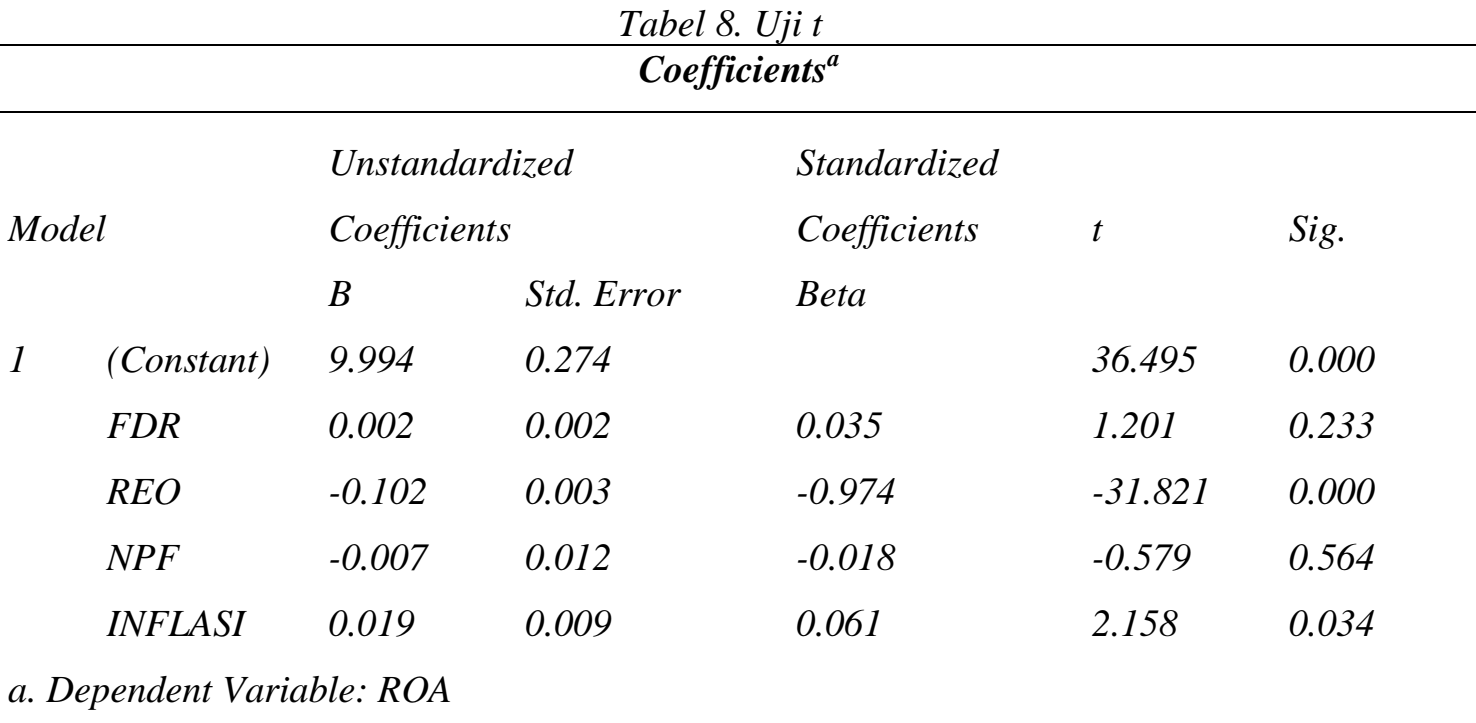


Berdasarkan Tabel 8, maka dapat dilakukan pembuktian hipotesis terhadap masing-masing variabel independen sebagai berikut:

1) Pembuktian Hipotesis 2

Pembuktian hipotesis 2 (dua) dilakukan dengan uji t. Berdasarkan Tabel 8 dihasilkan $t_{\text {hitung }}$ variabel $F D R=1,201<t_{\text {tabel }}=1,986$ atau signifikansi $0,233>0,05$, yang berarti tidak terdapat pengaruh yang signifikan antara FDR secara parsial terhadap ROA. Dengan demikian, hipotesis 2 (dua) yang menyatakan bahwa "Diduga FDR secara parsial berpengaruh signifikan terhadap ROA pada Bank Umum Syariah di Indonesia periode 2014-2019”, dinyatakan ditolak.

\section{2) Pembuktian Hipotesis 3}

Pembuktian hipotesis 3 (tiga) dilakukan dengan uji t. Berdasarkan Tabel 8 dihasilkan $t_{\text {hitung }}$ variabel $\mathrm{REO}=-|31,821|>\mathrm{t}_{\text {tabel }}=1,986$ atau signifikansi $0,000<0,05$, yang berarti terdapat pengaruh yang signifikan antara REO secara parsial terhadap ROA. Dengan demikian, hipotesis 3 (tiga) yang menyatakan bahwa "Diduga REO secara parsial berpengaruh signifikan terhadap ROA pada Bank Umum Syariah di Indonesia periode 2014-2019", dinyatakan diterima.

\section{3) Pembuktian Hipotesis 4}

Pembuktian hipotesis 4 (empat) dilakukan dengan uji t. Berdasarkan Tabel 8 dihasilkan $t_{\text {hitung }}$ variabel $\mathrm{NPF}=-|0,579|<\mathrm{t}_{\text {tabel }}=1,986$ atau signifikansi $0,564>0,05$, yang berarti tidak terdapat pengaruh yang signifikan antara NPF secara parsial terhadap ROA. Dengan demikian, hipotesis 4 (empat) yang menyatakan bahwa "Diduga NPF secara parsial berpengaruh signifikan terhadap ROA pada Bank Umum Syariah di Indonesia periode 2014-2019”, dinyatakan ditolak.

\section{4) Pembuktian Hipotesis 5}

Pembuktian hipotesis 5 (lima) dilakukan dengan uji t. Berdasarkan Tabel 8 dihasilkan $\mathrm{t}_{\text {hitung variabel Inflasi }}=2.158>\mathrm{t}_{\text {tabel }}=1,986$ atau signifikansi $0,034<0,05$, yang berarti terdapat pengaruh yang signifikan antara Inflasi secara parsial terhadap ROA. Dengan demikian, hipotesis 5 (lima) yang menyatakan bahwa "Diduga Inflasi secara parsial berpengaruh signifikan terhadap ROA pada Bank Umum Syariah di Indonesia periode 2014-2019", dinyatakan diterima.

\section{Pengaruh FDR, REO, NPF, dan Inflasi terhadap ROA}

Berdasarkan pembuktian hipotesis 1 (satu) menunjukkan bahwa variabel FDR, REO, NPF, dan Inflasi secara simultan berpengaruh signifikan terhadap ROA pada Bank Umum Syariah di Indonesia periode 2014-2019. Hal ini menunjukkan bahwa penggabungan variabel FDR, REO, NPF, dan Inflasi relevan digunakan sebagai estimasi dari ROA pada Bank Umum Syariah di Indonesia periode 2014-2019.

Berdasarkan hasil uji koefisien determinasi $\left(\mathrm{R}^{2}\right)$ (lihat Tabel 7), dihasilkan nilai Adjusted $R$ Square sebesar 0,952 atau 95,2\%. Hal ini menunjukkan bahwa variabel FDR, REO, NPF, dan Inflasi memberikan kontribusi pengaruh terhadap ROA sebesar 95,2 \%, sedangkan $4,8 \%$ sisanya dipengaruhi oleh variabel-variabel lain yang tidak dimasukkan ke dalam model penelitian ini. 
Analisis Pengaruh Financing To Deposit Ratio, Rasio Efisiensi Kegiatan Operasional, Non

Performing Financing, Dan Inflasi Terhadap Return On Asset pada Bank Umum Syariah di

Indonesia Periode 2014-2019

\section{Pengaruh FDR terhadap ROA}

Berdasarkan pembuktian hipotesis 2 (dua) menunjukkan bahwa variabel FDR secara parsial berpengaruh tidak signifikan terhadap ROA pada Bank Umum Syariah di Indonesia periode 2014-2019.

Semula diduga FDR secara parsial berpengaruh signifikan terhadap ROA. Hal tersebut sesuai dengan teori yang dikemukakan oleh Rivai dan Arifin (2010) yang menyatakan bahwa tinggi rendahnya rasio FDR menunjukkan tingkat likuiditas bank tersebut. Semakin tinggi rasionya memberikan indikasi rendahnya kemampuan likuditas bank tersebut, hal ini sebagai akibat jumlah dana yang diperlukan untuk penyaluran pembiayaan semakin besar. Bank wajib menyediakan likuiditas dengan cukup dan mengelolanya dengan baik, karena apabila likuiditas terlalu kecil akan mengganggu kegiatan operasional bank. Namun, likuiditas juga tidak boleh terlalu besar, karena akan menurunkan efisiensi bank sehingga berdampak pada rendahnya tingkat profitabilitas.

Namun, hasil penelitian ini menunjukkan bahwa FDR secara parsial berpengaruh tidak signifikan terhadap ROA. Hal ini disebabkan karena terdapat rasio FDR yang berada di luar batasan yang ditetapkan oleh Bank Indonesia dalam Peraturan Bank Indonesia Nomor 15/15/PBI/2013 tentang GWM Bank Umum dalam Rupiah, dimana BI menetapkan rasio FDR antara 78\% sampai 92\% (Mokoagow dan Fuady, 2015). FDR Bank Umum Syariah harus dijaga pada batas aman sesuai regulasi Bank Indonesia, karena jika penyaluran pembiayaan terlalu tinggi (lebih dari 92\%), maka akan menjadi ancaman bagi likuiditas bank tersebut. Sedangkan jika penyaluran pembiayaan terlalu rendah (kurang dari 78\%), maka prinsip bagi hasil bank syariah menjadi kurang menarik lagi bagi masyarakat atau nasabah sehingga berpengaruh terhadap profitabilitas, dan mengindikasikan bahwa fungsi intermediasi perbankan tidak berjalan optimal.

Berdasarkan aspek arah pengaruh menunjukkan bahwa variabel FDR secara parsial berpengaruh positif terhadap ROA pada Bank Umum Syariah di Indonesia periode 2014-2019, artinya semakin tinggi nilai FDR cenderung meningkatkan ROA. Hal ini sesuai dengan pandangan yang dikemukakan oleh Muhammad (2005), bahwa FDR dipergunakan untuk mengukur sampai sejauh mana dana pinjaman yang bersumber dari Dana Pihak Ketiga (DPK). Nilai FDR menunjukkan efektif tidaknya bank dalam menyalurkan pembiayaan. Apabila nilai FDR menunjukkan persentase tinggi, menandakan dana pihak ketiga yang disalurkan melalui pembiayaan semakin tinggi. Pembiayaan yang disalurkan secara optimal dan efektif, akan meningkatkan pendapatan bank yang selanjutnya akan meningkatkan pula laba atau profitabilitas yang diperoleh bank syariah. Sebaliknya, nilai FDR yang rendah, menandakan pihak bank kurang optimal dan efektif dalam penyaluran pembiayaan, sehingga pendapatan dan laba yang diperoleh juga sedikit (Riyadi dan Yulianto, 2014).

\section{Pengaruh REO terhadap ROA}

Berdasarkan pembuktian hipotesis 3 (tiga) menunjukkan bahwa variabel REO secara parsial berpengaruh signifikan terhadap ROA pada Bank Umum Syariah di Indonesia periode 2014-2019. Hal ini sesuai dengan pandangan yang dikemukakan oleh Kuncoro dan Suhardjono (2011) bahwa REO merupakan rasio perbandingan antara biaya operasional dengan pendapatan operasional dalam mengukur tingkat efisiensi dan kemampuan bank dalam menunjang kegiatan operasional. Ketika bank yang dalam kegiatan usahanya tidak efisien akan mengakibatkan ketidakmampuan bersaing dalam 
mengerahkan dana masyarakat maupun dalam menyalurkan dana tersebut kepada masyarakat yang membutuhkan dana sebagai modal usaha. Adanya efisiensi pada lembaga perbankan terutama efisiensi biaya maka akan diperoleh tingkat keuntungan optimal, penambahan jumlah dana yang disalurkan, biaya lebih kompetitif, peningkatan pelayanan kepada nasabah, serta peningkatan keamanan dan kesehatan bank. Sehingga apabila REO semakin rendah maka dapat meningkatkan ROA.

Berdasarkan aspek arah pengaruh menunjukkan bahwa REO secara parsial berpengaruh negatif terhadap ROA pada Bank Umum Syariah di Indonesia periode 20142019, artinya semakin tinggi nilai REO cenderung menurunkan ROA. Hal ini sesuai dengan pandangan yang dikemukakan oleh Rivai dan Arifin (2010) bahwa REO digunakan mengukur tingkat efisiensi dan kemampuan bank dalam menunjang kegiatan operasional. Semakin kecil rasio biaya (beban) operasionalnya akan lebih baik, karena biaya yang dikeluarkan lebih kecil dibandingkan pendapatan yang diterima. Adanya efisiensi biaya pada lembaga perbankan, akan diperoleh tingkat pendapatan yang optimal, yang selanjutnya semakin meningkatkan laba atau profitabilitas bank syariah. Selain itu dengan semakin tingginya laba bank syariah, berpengaruh kepada penambahan jumlah dana yang disalurkan, biaya lebih kompetitif, peningkatan pelayanan kepada nasabah, serta peningkatan keamanan dan kesehatan bank. Sebaliknya, semakin tinggi biaya operasional menandakan bank syariah semakin tidak efisien dalam kegiatan operasionalnya, yang berpengaruh kepada penurunan pendapatan dan selanjutnya akan menurunkan laba atau profitabilitas bank syariah.

\section{Pengaruh NPF terhadap ROA}

Berdasarkan pembuktian hipotesis 4 (empat) menunjukkan bahwa variabel NPF secara parsial berpengaruh tidak signifikan terhadap ROA pada Bank Umum Syariah di Indonesia periode 2014-2019.

Semula diduga NPF secara parsial berpengaruh signifikan terhadap ROA. Hal tersebut sesuai dengan teori Dendawijaya (2009) yang menyatakan bahwa implikasi bagi pihak bank sebagai akibat timbulnya pembiayaan bermasalah adalah hilangnya kesempatan untuk memperoleh pendapatan dari pembiayaan yang diberikan sehingga mengurangi perolehan laba dan berpengaruh buruk terhadap rentabilitas bank serta ROA akan mengalami penurunan.

Namun, hasil penelitian ini menunjukkan bahwa NPF secara parsial berpengaruh tidak signifikan terhadap ROA. Hal ini disebabkan karena bank syariah tidak hanya mengandalkan pendapatan yang dihasilkan dari pembiayaan untuk meningkatkan laba, tetapi juga berupaya meningkatkan perolehan laba melalui sumber-sumber atau produkproduk diluar pendapatan dari pembiayaan, yaitu pendapatan dari jasa-jasa perbankan lainnya. Pendapatan dari jasa tersebut diantaranya transfer, kliring, inkaso, save deposit box, kartu kredit, bank notes, bank garansi, bank draft, letter of credit (L/C), cek wisata (travellers cheque), penerimaan setoran pembayaran, dan jasa-jasa lainnya. Sekalipun sebagai kegiatan penunjang, kegiatan jasa-jasa perbankan lainnya ini banyak memberikan keuntungan bagi bank dan nasabah, sehingga kerugian akibat NPF dapat ditutupi oleh pendapatan diluar pembiayaan. Oleh karena itu, dengan meningkatnya NPF tidak berpengaruh signifikan terhadap ROA, karena pendapatan bank juga ditopang oleh pendapatan selain dari pembiayaan, yaitu pendapatan dari jasa-jasa perbankan lainnya (Kasmir, 2012). Selain itu, banyaknya rasio NPF yang masih berada di bawah batas aman yaitu 5\%, menyebabkan NPF tidak berpengaruh signifikan terhadap ROA. Berdasarkan 
Analisis Pengaruh Financing To Deposit Ratio, Rasio Efisiensi Kegiatan Operasional, Non

Performing Financing, Dan Inflasi Terhadap Return On Asset pada Bank Umum Syariah di

Indonesia Periode 2014-2019

Surat Edaran Bank Indonesia No. 13/24/DPNP tanggal 25 Oktober 2011 tentang Penilaian Tingkat Kesehatan Bank Umum, disebutkan bahwa batas aman NPF bank syariah yaitu dibawah $5 \%$.

Berdasarkan aspek arah pengaruh menunjukkan bahwa NPF secara parsial berpengaruh negatif terhadap ROA pada Bank Umum Syariah di Indonesia periode 20142019, artinya semakin tinggi nilai NPF cenderung menurunkan ROA. Hal ini sesuai dengan pandangan yang dikemukakan oleh IBI (2015) bahwa NPF merupakan rasio untuk mengetahui kualitas pembiayaan bank syariah. Semakin tinggi rasio NPF, menunjukkan kualitas pembiayaan Bank Syariah akan semakin buruk. Kualitas pembiayaan yang kurang baik atau bahkan memburuk, akan berdampak secara langsung pada penurunan pendapatan dan laba yang diperoleh Bank Syariah. Penurunan pendapatan dan laba tersebut selanjutnya menurunkan kemampuan bank syariah dalam menyalurkan pembiayaan lebih lanjut dan menjalankan bisnis lainnya .

\section{Pengaruh Inflasi terhadap ROA}

Berdasarkan pembuktian hipotesis 5 (lima) menunjukkan bahwa variabel Inflasi secara parsial berpengaruh signifikan terhadap ROA pada Bank Umum Syariah di Indonesia periode 2014-2019. Hal ini sesuai dengan pandangan yang dikemukakan oleh Karim (2010), bahwa inflasi dapat berpengaruh buruk bagi perekonomian, karena apabila terjadi inflasi yang parah maka keadaan perekonomian menjadi tidak stabil. Inflasi mengakibatkan melemahnya semangat menabung dan sikap terhadap menabung dari masyarakat atau turunnya Marginal Propensity to Save (MPS), sehingga minat masyarakat untuk menabung atau berinvestasi menjadi berkurang dan berakibat pada penurunan penyaluran pembiayaan serta menyebabkan adanya peningkatan pembiayaan bermasalah akibat nasabah tidak mampu membayar kembali pembiayaan yang ia terima. Hal ini akan berdampak pada turunnya profitabilitas bank syariah.

Berdasarkan aspek arah pengaruh menunjukkan bahwa Inflasi secara parsial berpengaruh positif terhadap ROA pada Bank Umum Syariah di Indonesia periode 20142019, artinya semakin tinggi nilai Inflasi cenderung meningkatkan ROA. Seharusnya secara teoritis variabel Inflasi berpengaruh negatif terhadap ROA. Hal ini didasarkan pada pandangan yang dikemukakan oleh Karim (2010), bahwa inflasi dapat berpengaruh buruk bagi perekonomian, karena apabila terjadi inflasi yang parah maka keadaan perekonomian menjadi tidak stabil. Inflasi mengakibatkan melemahnya semangat menabung dan sikap terhadap menabung dari masyarakat atau turunnya Marginal Propensity to Save (MPS), sehingga minat masyarakat untuk menabung atau berinvestasi menjadi berkurang dan berakibat pada penurunan penyaluran pembiayaan serta menyebabkan adanya peningkatan pembiayaan bermasalah akibat nasabah tidak mampu membayar kembali pembiayaan yang ia terima. Hal ini akan berdampak pada turunnya profitabilitas bank syariah.

Namun, hasil penelitian ini menunjukkan bahwa Inflasi secara parsial berpengaruh positif terhadap ROA, yang artinya ketika variabel Inflasi mengalami penurunan akan berdampak pada penurunan variabel ROA. Hal ini disebabkan karena inflasi aktual tergolong inflasi rendah yaitu dibawah $10 \%$ dan sesuai target inflasi yang ditetapkan pemerintah setiap tahunnya. Menurut Abduh dan Idrees (2013) Inflasi berpengaruh positif terhadap ROA karena pendapatan bank meningkat lebih dari biaya yang dikeluarkan selama waktu inflasi. Bank yang memprediksi tingkat inflasi dapat 
membantu bank dalam mengambil keputusan yang berkaitan dengan tingkat bagi hasil, kuantitas pinjaman dan kualitas aset. Selanjutnya, menurut Swandayani dan Kusumaningtias (2012) pada saat inflasi tinggi maka masyarakat lebih percaya terhadap perbankan syariah dibandingkan dengan perbankan konvensional. Kepercayaan masyarakat tersebut juga dimungkinkan karena adanya pengalaman historis pada saat terjadi krisis ekonomi pada tahun 1997, di mana pada masa tersebut tingkat inflasi di Indonesia sangat tinggi dan akhirnya mengakibatkan banyak bank konvensional yang mengalami kebangkrutan. Hal ini disebabkan karena bank konvensional menerapkan tingkat bunga yang terlalu tinggi untuk mengimbangi laju inflasi serta untuk menarik nasabah agar tetap menempatkan dananya, yang pada akhirnya bank tersebut tidak dapat mengembalikan dana masyarakat yang telah disimpan beserta bunganya. Pada saat krisis moneter yang terjadi pada tahun 1998, telah menenggelamkan bank-bank konvensional dan banyak yang dilikuidasi karena kegagalan sistem bunganya, perbankan yang menerapkan sistem syariah dapat tetap berdiri dan mampu bertahan. Hal ini dapat dibuktikan dari keberhasilan Bank Muamalat Indonesia melewati krisis yang terjadi pada tahun 1998. Sehingga variabel Inflasi dapat berpengaruh positif terhadap Return On Asset (ROA) pada Bank Umum Syariah.

\section{KESIMPULAN}

Berdasarkan hasil analisis dan pembahasan, maka diperoleh kesimpulan yang menunjukkan bahwa FDR, REO, NPF, dan Inflasi secara simultan berpengaruh signifikan terhadap ROA pada Bank Umum Syariah di Indonesia periode 2014-2019. Secara parsial, FDR berpengaruh positif dan tidak signifikan terhadap ROA pada Bank Umum Syariah di Indonesia periode 2014-2019, REO berpengaruh negatif dan signifikan terhadap ROA pada Bank Umum Syariah di Indonesia periode 2014-2019, NPF berpengaruh negatif dan tidak signifikan terhadap ROA pada Bank Umum Syariah di Indonesia periode 20142019, dan Inflasi berpengaruh positif dan signifikan terhadap ROA pada Bank Umum Syariah di Indonesia periode 2014-2019.

\section{REFERENSI}

Abduh, Muhamad, and Yameen Idrees. 2013. Determinants of Islamic Banking Profitability in Malaysia. Australian Journal of Basic and Applied Sciences. Volume 7 (2): 204-10.

Agustin, Priska Trias, and Ari Darmawan. 2018. Pengaruh Rasio Keuangan Terhadap Kinerja Keuangan Bank Syariah (Studi Pada Bank Umum Syariah Yang Terdaftar Di Otoritas Jasa Keuangan Republik Indonesia Tahun 2014-2016). Jurnal Administrasi Bisnis. Volume 64 (1): 102-108.

Ali, Khizer, Muhammad Farhan Akhtar dan Hafiz Zafar Ahmed. 2011. Bank-Specific and Macroeconomic Indicators of Profitability-Empirical Evidence from the Commercial Banks of Pakistan. International Journal of Business and Social Science. Volume 2 (6): 235-242.

Ardana, Yudhistira. 2018. Faktor Eksternal Dan Internal Yang Mempengaruhi Profitabilitas Bank Syariah Di Indonesia. Cakrawala: Jurnal Studi Islam. Volume 13 (1): 51-59.

Dendawijaya, Lukman. 2009. Manajemen Perbankan. Bogor: Ghalia Indonesia. 
Analisis Pengaruh Financing To Deposit Ratio, Rasio Efisiensi Kegiatan Operasional, Non Performing Financing, Dan Inflasi Terhadap Return On Asset pada Bank Umum Syariah di Indonesia Periode 2014-2019

Ghozali, Imam. 2006. Aplikasi Analisis Multivariate Dengan Program SPSS. Semarang: Badan Penebit Universitas Diponogoro.

Hidayati, Amalia Nuril. 2014. Pengaruh Inflasi, BI Rate Dan Kurs Terhadap Profitabilitas Bank Syariah Di Indonesia. An-Nisbah: Jurnal Ekonomi Syariah. Volume 1 (1): 72-97.

Hooshyari, Naser, dan Abdollah Pakdel Moghanloo. 2015. Evaluating the Impact of Inflation on Profitability of Banks. Kuwait Chapter of Arabian Journal of Business and Management Review. Volume 4 (9): 19-23.

Husnan, Suad, dan Enny Pudjiastuti. 2015. Dasar-Dasar Manajemen Keuangan. Yogyakarta: UPP AMP YKPN.

IBI. 2015. Mengelola Bisnis Pembiayaan Bank Syariah. Jakarta: PT. Gramedia Pustaka Utama.

Janah, Nur, dan Pani Akhiruddin Siregar. 2018. Pengaruh Rasio Keuangan Terhadap Profitabilitas Perbankan Syariah Indonesia. AT-TAWASSUTH: Jurnal Ekonomi Islam. Volume 3 (1): 163-183.

Karim, Adiwarman A. 2010. Ekonomi Makro Islami. Jakarta: PT. RajaGrafindo Persada.

Kasmir. 2012. Dasar-Dasar Perbankan. Jakarta: PT. RajaGrafindo Persada.

Kuncoro, Mudrajad. 2013. Metode Riset Untuk Bisnis dan Ekonomi. Jakarta: Erlangga.

Kuncoro, Mudrajad, dan Suhardjono. 2011. Manajemen Perbankan: Teori dan Aplikasi. Yogyakarta: BPFE.

Lemiyana, dan Erdah Litriani. 2016. Pengaruh NPF, FDR, BOPO Terhadap Return On Asset (ROA) Pada Bank Umum Syariah. I-Economics: A Research Journal on Islamic Economics. Volume 2 (1): 31-49.

Mokoagow, Sri Windarti, dan Misbach Fuady. 2015. Faktor-Faktor Yang Mempengaruhi Profitabilitas Bank Umum Syariah Di Indonesia. EBBANK. Volume 6 (1): 33-62.

Muhamad. 2016. Manajemen Pembiayaan Bank Syariah. Yogyakarta: UPP AMP YKPN.

Muhammad. 2005. Manajemen Bank Syariah. Yogyakarta: UPP AMP YKPN.

Peraturan Bank Indonesia Nomor 15/15/PBI/2013 Tentang Giro Wajib Minimum Bank Umum Dalam Rupiah Dan Valuta Asing Bagi Bank Umum Konvensional (diakses pada tanggal 19 Mei 2020).

Rivai, Veithzal, dan Arviyan Arifin. 2010. Islamic Banking: Sebuah Teori, Konsep, Dan Aplikasi. Jakarta: PT. Bumi Aksara.

Riyadi, Slamet, dan Agung Yulianto. 2014. Pengaruh Pembiayaan Bagi Hasil, Pembiayaan Jual Beli, Financing To Deposit Ratio (FDR) Dan Non Performing Financing (NPF) Terhadap Profitabilitas Bank Umum Syariah Di Indonesia. Accounting Analysis Journal. Volume 3 (4): 466-474. 
Riyanto, Bambang. 2013. Dasar-Dasar Pembelanjaan Perusahaan. Yogyakarta: BPFE.

Rudianto. 2013. Akuntansi Manajemen Informasi Untuk Pengambilan Keputusan Strategis. Jakarta: Erlangga.

Simorangkir, O. P. 2004. Pengantar Lembaga Keuangan Bank Dan Non Bank. Bogor: Ghalia Indonesia.

Sumarlin. 2016. Analisis Pengaruh Inflasi, CAR, FDR, BOPO, Dan NPF Terhadap Profitabilitas Perbankan Syariah. ASSETS. Volume 6 (2): 296-313.

Sunyoto, Danang. 2011. Analisis Regresi Dan Uji Hipotesis. Yogyakarta: Media Pressindo.

Surat Edaran Bank Indonesia No. 13/24/DPNP Tanggal 25 Oktober 2011 Tentang Penilaian Tingkat Kesehatan Bank Umum (diakses pada tanggal 23 Maret 2020).

Suwiknyo, Dwi. 2016. Analisa Laporan Keuangan Perbankan Syariah. Yogyakarta: Pustaka Pelajar.

Swandayani, Desi Marilin, dan Rohmawati Kusumaningtias. 2012. Pengaruh Inflasi, Suku Bunga, Nilai Tukar Valas, Dan Jumlah Uang Beredar Terhadap Profitabilitas Pada Perbankan Syariah Di Indonesia Periode 2005-2009. AKRUAL. Volume 3 (2): 147-166.

Syah, Toufan Aldian. 2018. Pengaruh Inflasi, BI Rate, NPF, Dan BOPO Terhadap Profitabilitas Bank Umum Syariah Di Indonesia. El-JIZYA Jurnal Ekonomi Islam. Volume 6 (1): 133-53.

Taswan. 2017. Manajemen Perbankan Konsep, Teknik, Dan Aplikasi. Yogyakarta: UPP STIM YKPN.

Undang-Undang Republik Indonesia Nomor 21 Tahun 2008 Tentang Perbankan Syariah (diakses pada tanggal 24 Januari 2020).

Widati, Listyorini Wahyu. 2012. Analisis Pengaruh CAMEL Terhadap Kinerja Perusahaan Perbankan Yang Go Public. Dinamika Akuntansi, Keuangan Dan Perbankan. Volume 1 (2): 105-119.

Yunita, Rima. 2014. Faktor-Faktor Yang Mempengaruhi Tingkat Profitabilitas Perbankan Syariah Di Indonesia. Jurnal Akuntansi Indonesia. Volume 3 (2): 143-160. 